доктор історичних наук, професор кафедри туристичної інфраструктури і сервісу ДВНЗ «Ужгородський національний університет»(Украӥна, Ужгород), korsakr@i.ua

\title{
ТЕНДЕНЦІї РОЗВИТКУ ДІЛОВОГО ТУРИЗМУ У СВІТІ
}

У статті комплексно проаналізовано тендениії та сучасний розвиток ділового туризму у світі. Проаналізувавши світовий досвід розвитку ділового туризму, можна констатувати, щзо його найбільиими лідерами у світі є краӥни Західної Свропи та Північної Америки. Актуальність теми дослідження зумовлена тим, ияо діловий туризм - ефективний засіб доступності наукових иінностей та дієве джерело збереження і пізнання суспільної спадщчини

Автор використав загальнонаукові та спеціальнонаукові методи дослідження. Зокрема, метод аналізу, синтезу, діалектичний метод, метод історизму, історико-хронологічний тощо. У науковому доробку віддано перевагу історичним методам дослідження: історико-генетичному, історико-порівняльному, історико-синтетичному, історико-діахронному, емпіричному аналізу тощзо.

Ключові слова: діловий туризм, конгресовий туризм, науковий туризм, екологічний туризм, конференції, освітній туризм.

Лim. 24.

Roman KORSAK,

PhD hab. (History), Professor of tourism infrastructure and services department, Uzhgorod National University (Ukraine, Uzhgorod), korsakr@inbox.ru

\section{TRENDS OF BUSINESS TOURISM IN THE WORLD}

The article comprehensively analyzes the current trends and the development of business tourism in the world. Analyzing the international experience of business travel, we can say that the greatest leaders of business tourism in the world are the countries of Western Europe and North America. The background research is due to the fact that business tourism is an effective means availability of scientific values and effective source of knowledge preservation and social heritage.

The paper uses general science and special scientific methods. In particular, the method of analysis, synthesis, dialectical method, historicism, historical and chronological metod more. In the preferred scientific heritage historical methods of research: historical and genetic, historical and comparative, historical and synthetic, historical and diachronic, empirical analysis and more.

Keywords: business tourism, congress tourism, scientific tourism, eco-tourism, conferences, educational tourism.

Ref. 24.

Роман КОРСАК,

доктор исторических наук, профессор кафедры туристической инфраструктуры и сервиса ГВУЗ «Ужсгородский национальный университет» (Украина, Ужсгород), korsakr@inbox.ru

\section{ТЕНДЕНЦИИ РАЗВИТИЯ ДЕЛОВОГО ТУРИЗМА В МИРЕ}

В статье комплексно проанализированы тенденции и современное развитие делового туризма в мире. Проанализировав мировой опыт развития делового туризма, можно констатировать, что его лидерами в мире являются страны Западной Европь и Северной Америки. Актуальность темы исследования обусловлена тем, что деловой туризм - эффективное средство доступности научных иееностей и действенный источник сохранения и познания общественной наследия.

Автор использовал общенаучные и специильные научные методы исследования. В частности, метод анализа, синтеза, диалектический метод, метод историзма, историко-хронологический и др. В научной работе отдано предпочтение историческим методам исследования: историко-генетическому, историко-сравнительному, историко-синтетическому, историко-диахронному, эмпирическому анализу. 
Ключевые слова: деловой туризм, конгрессный туризм, научный туризм, экологический туризм, конференции, образовательный туризм.

Лит. 24.

Постановка проблеми. Популярність ділового туризму пов'язана насамперед 3 тим, що на сучасному етапі у суспільній свідомості відбуваються істотні зміни у розумінні глобальних процесів, які забезпечують прогресивний розвиток суспільства. Актуальність теми дослідження зумовлена тим, що діловий туризм є ефективним засобом доступності наукових цінностей та дієвим джерелом збереження і пізнання суспільної спадщини через його використання.

Аналіз досліджень. Водночас зауважимо, що діловий або як його ще називають - науковий туризм, у вітчизняній бібліографії достатньою мірою не досліджується. Сучасний стан вітчизняного ділового туризму в Україні досліджують: Т. Казакова (діловий туризм у галузі індустріального туризму) [1], О. Ляховин, К. Міщук та М. Черезова (мовний, освітній і науковий туризм: формування, розвиток термінології та педагогічні аспекти) $[4 ; 7 ; 12]$. Проблеми та перспективи розвитку ділового туризму в Україні аналізує С. Нікітенко [8].

Що стосується зарубіжної літератури, то ця тема опосередковано розглядається іноземними авторами, зокрема, Н. Красовською [3], Р. Балтером [14], Ю. Холодиліною та ін. [10; 11; 13; 15; 16; $17 ; 18 ; 19 ; 20 ; 21 ; 22 ; 23]$. Маємо констатувати, що в українській і зарубіжній літературі означена проблематика висвітлена недостатньо.

Мета статті - дослідити особливості розвитку та сучасний стан ділового туризму у світі.

Виклад основного матеріалу. Діловий туризм є одним з найбільш динамічніших сегментів ринку сучасних подорожей. Це пояснюється зростанням у світі інтересу до таких ділових заходів:

- конференцій;

- симпозіумів;

- нарад;

- семінарів;

- виставок і ярмарків.

Бізнесмени та вчені беруть участь у форумах, щоб зустрітися з колегами, обмінятися науковим досвідом і найновішою інформацією, провести переговори, відволіктися від звичної обстановки та долучитися до пропонованої культурної програми [2, 89-98].

Якщо у 30-ті pp. ХX ст. щорічно проводилось близько 200 міжнародних конференцій, то сьогодні їхня щорічна кількість перевищує 9 тис., причому близько 80 \% припадає на країни Західної Європи та Північної Америки. Перші три позиції за кількістю міжнародних симпозіумів і нарад посідають:

1. США;

2. Франція;

3. Велика Британія.

Німеччина, яка займає четверте місце, відома своїми виставками та ярмарками, популярність яких пояснюється такими чинниками:

1. Сприятливою кон'юнктурою у багатьох галузях промисловості;

2. Підвищеним попитом на інвестиційні товари і розвиненою інфраструктурою.

Так, неоднаразово ця європейська країна отримувала право проводити всесвітню виставку «Експо» у Ганновері - відомому конгресовому та виставковому центрі. Зокрема, у 2000 р. тут було представлено 189 країн, що розмістилися у 53-х павільйонах на площі 170 га. Основну частину площі зайняла експозиція на тему «Людство - Природа - Технологія» [3, 79-85].

Необхідно відзначити, що сьогодні найбільшими центрами конгресово-виставкової діяльності в Європі та Америці є такі міста: Амстердам (Ніделанди), Барселона та Мадрид (Іспанія), Брюссель (Бельгія), Вашингтон (США), Женева (Швейцарія), Копенгаген (Данія), Лондон (Великобританія), Париж (Франція).

Щороку державні та ділові особи з'їжджаються до Давоса (Швейцарія) на форуми з актуальних питань розвитку світового господарства. Ці міста мають відповідну матеріально-технічну базу та широкі можливості для організації дозвілля іноземних гостей. Конференції відбуваються у конгрес-центрах, готелях, театрах і концертних залах, університетах та інших закладах. Остан- 
нім часом міжнародні заходи дедалі частіше проводяться у будівлях, які мають історичне значення, - у замках чи нетрадиційних спорудах. Користуються популярністю конгреси на борту суден. Часто симпозіуми і конференції проходять у теплу пору року на узбережжях морів чи озер.

Особливе значення для просування туристичного продукту мають спеціалізовані туристичні виставки та біржі. Основними цілями таких міжнародних заходів $є$, зокрема, вивчення попиту на туристичні послуги, укладання договорів, встановлення ділових контактів та ін. [9, 169-173].

Виставки можуть бути двох типів: всесвітніми та регіональними.

Найбільш значні міжнародні виставки і ярмарки є щорічними і проводяться у визначений період року - перед початком літнього чи зимового сезону за заздалегідь визначеними датами i тривають до одного тижня.

Вони супроводжуються такими заходами: прес-конференціями та виставками літератури: проспектів, буклетів, листівок, календарів, карт, схем та путівників, значків, іншої сувенірної продукції тощо

Відзначимо, що кількість таких заходів постійно зростає. Тільки у Європі щорічно організовується понад 200 міжнародних туристичних виставок і бірж [2, 89-98; 22, 48-59].

Зокрема, одна 3 найбільших у світі туристичних виставок - Міжнародна туристична біржа (ITB). Вона проводиться у Берліні з 1966 р. щорічно в березні протягом 7 днів. Один день виділяється тільки для професійних учасників, а в інші дні біржа відкрита для усіх охочих. У ній беруть участь представники державних міністерств, відомств, комітетів і рад з туризму, національні й регіональні туристичні організації, турфірми, туроператори і турагенти, готелі і готельні ланцюги, авіа- та круїзні компанії, структури систем бронювання та ін. У рамках біржі проводяться переговори між представниками закордонних організацій і комерційних туристичних компаній $[5,67-70]$.

У виставковому комплексі розміщуються величезні павільйони світових лідерів на ринку туризму - Німеччини, США, Франції, Іспанії, а також стенди початківців.

Робота берлінської біржі будується за принципом тематичних днів. Наприклад, вони можуть присвячуватися екологічному туризму в Свропі, перспективам розвитку туристичного руху в Африці тощо. У межах обраних тем організатори виставки пропонують широку програму спеціалізованих заходів: презентацій, “круглих столів”, форумів [6].

Найбільшою в Свропі за кількістю відвідувачів стала Міжнародна туристична виставка (SIT) у м. Штутгарті, що проводиться щорічно в партнерстві з різними країнами. Вона перевершує останнім часом Берлінську міжнародну туристичну біржу.

Всесвітній ринок подорожей у Лондоні проводиться з 1980 р. щорічно в листопаді-грудні протягом 5 днів за участю турфірм, представників туріндустрії і засобів інформації. Поряд із укладанням угод важливим завданням Лондонського ринку є ознайомлення 3 нововведеннями у сфері туризму [2, 89-98].

Щорічно наприкінці січня - на початку лютого в Мадриді відбувається Міжнародна туристична виставка-біржа ФІТЮР, яка посідає особливе місце в календарі міжнародних туристичних подій - саме тут визначаються цінові та інші тенденції на ринку туризму в новому сезоні [6].

Виставка-біржа ФІТЮР - це перегляд передусім іспанського та латиноамериканського туристичних продуктів, через що iï називають своєрідним мостом між Європою і Америкою. Чверть виставкової площі займають стенди країн Центральної та Південної Америки: Бразилії, Домініканської Республіки, Венесуели, Ямайки; Гондурасу та ін. У виставці також беруть участь туристичні фірми з країн Північної, Центральної та Східної Свропи, зі США та Канади, в яких відпочинок в Іспанії користується високим попитом. У 2005 р. виставка відзначила свій 25 -літній ювілей. До її роботи були приурочені численні конференції та семінари, форум з ділового та наукового туризму $[3,79-85]$.

Щорічно у середині листопада в Лондоні відбувається Всесвітня туристична виставка, призначена винятково для налагодження прямих контактів між спеціалістами різних країн. У дні ії роботи організатори проводять низку благочинних акцій, а зібрані кошти спрямовують у фонд Британського Червоного Хреста. Маємо констатувати, що кожного року кількість і географія учасників лондонської виставки розширюються, а кількість експонатів збільшується на 100- 
120 одиниць. Для їх розміщення потрібні додаткові площі, знайти які стає все складніше, тому організатори виставки розглядають питання про іiі переміщення у більш потужний виставковий комплекс Лондона або в інше місто Великої Британії.

Міжнародна туристична біржа у Мілані відома далеко за межами Італії, оскільки на неї з’їжджаються представники туристичного бізнесу з усього світу. Найбільшою є експозиція Італії, яка зазвичай займає кілька павільйонів. Як завжди, на виставці потужно представлені такі країни: Франція, Іспанія, Німеччина, Австрія та США.

Також тут є стенди країн, які не часто беруть участь у роботі лондонської та берлінської бірж. Наприклад, 1998 р. у Мілані велику цікаву експозицію розгорнула Куба. У межах цієї виставки щорічно реалізуються різноманітні тематичні програми, презентуються найновіші технології туризму [6].

Великим авторитетом користуються також:

1. Ляйпцигський ярмарок подорожей;

2. Міжнародний салон з туризму і подорожей, що проводиться щорічно у середині лютого у Парижі протягом 7-10 днів;

3. Міжнародна туристична біржа в Мілані - у другій половині лютого протягом 5 днів;

4. Міжнародна туристична виставка країн Азійського регіону (Гонконг);

5. Міжнародний туристичний ярмарок (Чикаго);

6. Міжнародна виставка «Туризм» (Гетеборг);

7. Міжнародна туристична виставка «Філоксенія» (Салоніки) та ін.

Можемо зазначити, що виставковий рух, як підвид ділового туризму, пожвавлюється в усьому світі. Зростає кількість виставок і ярмарків, розширюються їх географія та коло учасників, урізноманітнюються напрями. Сьогодні проводяться спеціалізовані виставки:

1. Готельного та ресторанного господарства;

2. Спортивного, екологічного, пізнавального та конгресового туризму;

3. Ярмарки туристичного і спортивного спорядження тощо. Вважаємо, що за короткий час цей сегмент туристичного ринку став одним із найпотужніших і стабільних у світовому діловому туризмі [24, 9-12].

Висновки. Отже, можна зробити висновки, що діловий туризм - порівняно новий вид туристичної індустрії. 3 приводу незначної кількості досліджень цього виду туризму виникло різне його трактування (науковий, конгресний, освітній тощо). Основною відмінною ознакою ділового туризму від будь-яких інших видів туризму є активна участь туриста у турі, а не просто отримання цікавої інформації та споглядання об'єктів. Проаналізувавши світовий досвід розвитку ділового туризму, можна констатувати, що найбільші лідери ділового туризму у світі - країни Західної Європи та Північної Америки.

\section{СПИСОК ВИКОРИСТАНИХ ДЖЕРЕЛ І ЛІТЕРАТУРИ}

1. Казакова Т. А. Науковий туризм у галузі індустріального туризму / Т. А. Казакова // Туристична індустрія: сучасний стан та пріоритети розвитку: матер. IV Міжнар. наук-практ. конф. - Луганськ: Вид-во ДЗ «ЛНУ ім. Т. Шевченка», 2011. - Вип. 6. - С. 118-123.

2. Конон П. С. Міжнародний бізнес-туризм: Інтерпретація дефініції та перспективи розвитку у XXI ст. / П. С. Конон // Вісник ДНУ. Серія: Світове господарство і міжнародні економічні відносини. 2012. - Вип. 4. - С. 89-98.

3. Красовская Н. А. Генезис конгрессного туризма и факторы, определяющие его развитие / Н. А. Красовская // Экономический журнал. - 2016. - № 2 (42). - С. 79-85.

4. Ляховин О. Мовний, освітній і науковий туризм: формування і розвиток термінології (на матеріалі української, російської і німецької мов) / О. Ляховин // Вісник Львівського університету. Серія філологічна. 2011. - Вип. 52. - С. 164-170.

5. Максимюк М. Н. Оценка состояния и перспективы развития делового туризма в Украине / М. Н. Максимюк // Культура народов Причерноморья. - 2012. - № 234. - С. 67-70.

6. Мальська М. П. Міжнародний туризм і сфера послуг: підручник / М. П. Мальська, Н. В. Антонюк. К., 2008. - 661 с. [Електронний ресурс] - Режим доступу: http://westudents.com.ua/knigi/603-mjnarodniyturizm-sfera-poslug-malska-mp.html 
7. Міщук К. С. Можливості і форми освітнього туризму в розвитку професійних компетенцій менеджера / К. С. Міщук, В. В. Стадник // Вісник Хмельницького національного університету. Економічні науки. - 2012. - № 4. - Т. 1. - С. 91-94.

8. Нікітенко С.І. Діловий туризм в Україні: проблеми та перспективи розвитку / С. І. Нікітенко // Наукові праці Чорноморського державного університету імені П. Могили. - 2006. - Т. 52. - Вип. 39. - С. 139-143.

9. Холодилина Ю. Е. Ресурсный потенциал региона как основа развития научного туризма / Ю. Е. Холодилина // Вестник Оренбургского государственного университета. - 2012. - № 8 (132). - С. 169173.

10. Холодилина Ю. Е. Социально-экономическая эффективность формирования региональной системы научного туризма / Ю. Е. Холодилина // Вестник Оренбурского государственного университета. 2014. - № 8 (169). - C. 148-153.

11. Холодилина Ю. Е. Теоретические аспекты развития научного туризма в регионе / Ю. Е. Холодилина // Вестник Оренбурского государственного университета. - 2011. - № 13 (132). - С. 500-506.

12. Черезова М. В. Педагогічні ознаки екскурсії / М. В. Черезова // Вісник ЛНУ імені Тараса Шевченка. - 2009. - №10. - С. 96-103.

13. Blangy S. Ecotourism in Europe: Two Views / S. Blangy, P. Hanneberg // The Ecotourism Society Newsletter. - 1995. - № 5(2). - P. 1-3.

14. Bulter R. Toutrism and Indigenous Peopls / R. Bulter, T. Hinch. - London: ITBP, 1996. -134 p.

15. Gordes K. Millennium Trails and Scenic Byways: Recreation in the 21st Century / K. Gordes // The Journal of Physical Education, Recreation \& Dance. - 2001. - № 72. - P. 21-32.

16. Higgins B. R. The Global Structure of the Nature Tourism Industry: Ecotourists, Tour Operators and Local Businesses / B. R. Higgins // Journal of Tourism Research. - 1998. - № 7 (3). - P. 20-39.

17. Jafari J. Anatomy of the travel industry / J. Jafari // Cornell Hotel and Restaurant Administration Quarterly. - 1983. - Vol. 24. - № 1. - P. 71-77.

18. Ksan historical villace. [Електронний ресурс]. - Режим доступу: http://www.ksan.org/index.htm.

19. Kurek W. Turystyka na obszarach gyrskich Europy / W. Kurek. - Kraków: Instytut Geografii i Gospodarki Przeztrzennej Uniwersytetu Jagiellonskiego, 2004. - 214 s.

20. Macintosh R. W. Tourism: principles, practices, philosophies. / R. W. Macintosh, Ch. R. Goeldner, J. R. B. Ritchie. - New York, 1995. - 421 s.

21. Malinowski G. Etnoturistika - touristika etnizna w Polsce / G. Malinowski. [Електронний ресурс]. Режим доступу: http://artelis. pl/artykuly/9521/ etnoturistika-touristika-etnizna-w-polsce.

22. Novacká L. Cestovný ruch, technika služieb, delegát a sprievodca / Ludmila Novacká a kolektív. - Bratislava: Vydavatel'stvo «Ekonóm». - 2011. - $471 \mathrm{~s}$.

23. Ritchie J.R.B. Culture as determinant of the attractiveness of a tourism region / J.R.B. Ritchie, M. Zins // Annals of Tourism Research. - 1998. - April-june. - P. 256.

24. UNWTO Tourism highlights 2016. - Edition. $-16 \mathrm{~s}$.

\section{REFERENCES}

1. Kazakova T. A. Naukovyi turyzm u haluzi industrialnoho turyzmu / T. A. Kazakova // Turystychna industriia: suchasnyi stan ta priorytety rozvytku: mater. IV Mizhnar. nauk-prakt. konf.- Luhansk: Vyd-vo DZ «LNU im. T. Shevchenka», 2011. - Vyp. 6. - S. 118-123.

2. Konon P. S. Mizhnarodnyi biznes-turyzm: Interpretatsiia definitsii ta perspektyvy rozvytku u XXI st. / P. S. Konon // Visnyk DNU. Seriia: Svitove hospodarstvo i mizhnarodni ekonomichni vidnosyny. - 2012. - Vyp. 4. S. 89-98.

3. Krasovskaya N. A. Genezis kongressnogo turizma i faktory, opredelyayushchie ego razvitie / N. A. Krasovskaya // Ekonomicheskiy zhurnal. - 2016. - № 2 (42). - S. 79-85.

4. Liakhovyn O. Movnyi, osvitnii i naukovyi turyzm: formuvannia i rozvytok terminolohii (na materiali ukrainskoi, rosiiskoi i nimetskoi mov) / O. Liakhovyn // Visnyk Lvivskoho universytetu. - Seriia filolohichna. 2011. - Vyp. 52. - S. 164-170.

5. Maksimyuk M. N. Otsenka sostoyaniya i perspektivy razvitiya delovogo turizma v Ukraine / M. N. Maksimyuk // Kultura narodov Prichernomorya. - 2012. - № 234. - S. 67-70.

6. Malska M. P. Mizhnarodnyi turyzm i sfera posluh: pidruchnyk / M. P. Malska, N. V. Antoniuk. - K., 2008. - 661 s. [Elektronnyi resurs]. - Rezhym dostupu: http://westudents.com.ua/knigi/603-mjnarodniy-turizmsfera-poslug-malska-mp.html

7. Mishchuk K. S. Mozhlyvosti i formy osvitnoho turyzmu v rozvytku profesiinykh kompetentsii menedzhera / K. S. Mishchuk, V. V. Stadnyk // Visnyk Khmelnytskoho natsionalnoho universytetu. Ekonomichni nauky. 2012. - № 4. - T. 1. - S. 91-94. 
8. Nikitenko S.I. Dilovyi turyzm v Ukraini: problemy ta perspektyvy rozvytku / S. I. Nikitenko // Naukovi pratsi Chornomorskoho derzhavnoho universytetu imeni P. Mohyly. - 2006. - T. 52. - Vyp. 39. - S. 139-143.

9. Kholodilina Yu. Ye. Resursnyy potentsial regiona kak osnova razvitiya nauchnogo turizma / Yu. Ye. Kholodilina // Vestnik Orenburgskogo gosudarstvennogo universiteta. - 2012. - № 8 (132). - S. 169-173.

10. Kholodilina Yu. Ye. Sotsialno-ekonomicheskaya effektivnost formirovaniya regionalnoy sistemy nauchnogo turizma / Yu. Ye. Kholodilina // Vestnik Orenburskogo gosudarstvennogo universiteta. - 2014. - № 8 (169). - S. 148-153.

11. Kholodilina Yu. Ye. Teoreticheskie aspekty razvitiya nauchnogo turizma v regione / Yu. Ye. Kholodilina // Vestnik Orenburskogo gosudarstvennogo universiteta. - 2011. - № 13 (132). - S. 500-506.

12. Cherezova M. V. Pedahohichni oznaky ekskursii / M. V. Cherezova // Visnyk LNU imeni Tarasa Shevchenka. - 2009. - № 10. - S. 96-103.

13. Blangy S. Ecotourism in Europe: Two Views / S. Blangy, P. Hanneberg // The Ecotourism Society Newsletter. - 1995. № 5(2). - P. 1-3.

14. Bulter R. Toutrism and Indigenous Peopls / R. Bulter, T. Hinch. - London: ITBP, 1996. - 134 p.

15. Gordes K. Millennium Trails and Scenic Byways: Recreation in the 21st Century / K. Gordes // The Journal of Physical Education, Recreation \& Dance. - 2001. - № 72. - P. 21-32.

16. Higgins B. R. The Global Structure of the Nature Tourism Industry: Ecotourists, Tour Operators and Local Businesses / B. R. Higgins // Journal of Tourism Research. - 1998. - № 7 (3). - P. 20-39.

17. Jafari J. Anatomy of the travel industry / J. Jafari // Cornell Hotel and Restaurant Administration Quarterly. - 1983. - Vol. 24. - № 1. - P. 71-77.

18. Ksan historical villace. [Elektronnyi resurs]. - Rezhym dostupu: http://www.ksan.org/index.htm.

19. Kurek W. Turystyka na obszarach gurskich Europy / W. Kurek. - Kraków: Instytut Geografii i Gospodarki Przeztrzennej Uniwersytetu Jagiellonskiego, 2004. - 214 s.

20. Macintosh R. W. Tourism: principles, practices, philosophies. / R. W. Macintosh, Ch. R. Goeldner, J. R. B. Ritchie. - New York, 1995. - 421 s.

21. Malinowski G. Etnoturistika - touristika etnizna w Polsce / G. Malinowski. [Elektronnyi resurs]. Rezhym dostupu: http://artelis. pl/artykuly/9521/ etnoturistika-touristika-etnizna-w-polsce.

22. Novacka L. Cestovne ruch, technika sluhieb, delegat a sprievodca / L. Novacka a kolektiv. - Bratislava: Vydavatel'stvo «Ekonóm». - 2011. - $471 \mathrm{~s}$.

23. Ritchie J.R.B. Culture as determinant of the attractiveness of a tourism region / J.R.B. Ritchie, M. Zins // Annals of Tourism Research. - 1998. - April-june. - P. 256.

24. UNWTO Tourism highlights 2016. - Edition. $-16 \mathrm{~s}$.

Стаття надійшла до редакиії 16.02.2017 p. 